\title{
PELATIHAN PENULISAN PROPOSAL KEGIATAN DAN SURAT MENYURAT PADA KARANG TARUNA DI LINGKUNGAN RW. 10 PERMATA MANSION, SERUA, BOJONGSARI, DEPOK
}

\author{
${ }^{1}$ Tri Pujiati, ${ }^{2}$ Varatisha Anjani Andullah, ${ }^{3}$ Yuli Iskandari, \\ ${ }^{4}$ Ratna Juwitasari Emha \\ Dosen Program Studi Sastra Indonesia, Universitas Pamulang \\ Email : ${ }_{\text {dosen00356@unpam.ac.id }}$
}

\begin{abstract}
ABSTRAK
Karang taruna merupakan sebuah organisasi pemuda yang memiliki wadah untuk menyampaikan aspirasi di kalangan remaja. Mitra dalam program ini adalah Karang Taruna di wilayah RW 04 Permata Mansion Serua, Bojongsari, Sawangan, Depok, Jawat Barat. Masalah utama yang dihadapi oleh mitra adalah sulitnya menulis proposal kegiatan sesuai dengan standar penulisan proposal kegiatan sehingga berdampak pada sulitnya karang taruna dalam mendapatkan sponsor dalam setiap kegiatan yang akan mereka lakukan. Upaya yang kami lakukan sebagai bentuk penyelesaian terhadap permasalahan yang dihadapi oleh mitra adalah dengan memberikan pelatihan penulisan proposal kegiatan yang sesuai dengan standar baku dalam penulisan proposal kegiatan dengan menggunakan bahasa Indonesia yang baik dan benar. Tidak hanya itu, solusi yang kami tawarkan adalah melakukan pendampingan terhadap karang taruna pada saat akan menulis proposal kegiatan sehingga mereka terbiasa untuk menulis proposal kegiatan dengan baik dan benar sesuai dengan standar penulisan proposal kegiatan. Langkah berikutnya yang kami tawarkan adalah pelatihan dalam membuat surat menyurat resmi sesuai dengan standar baku bahasa Indonesia yang baik dan benar sehingga karang taruna di RW 10 Permata Mansion mengetahui cara menulis surat-menyurat sesuai dengan standar baku bahasa Indonesia.
\end{abstract}

\section{Kata Kunci: Karang taruna, Proposal kegiatan, dan Surat Menyurat}

\section{PENDAHULUAN}

Karang taruna yang berada di wilayah Kota Depok khususnya di RW 10 Permata Mansion, Serua, Bojongsari Depok, merupakan salah satu perwujudan organisasi pemuda yang berada di tingkat RW. Sejak pemekaran wilayah dan terbentuknya RW 10 Cluster Emerald Permata Mansion pada tahun 2015 maka mulai dibentuklah organisasi karang taruna. Karang taruna sebagaimana tercantum dalam peraturan Menteri Sosial NO. 83/HUK/2005 merupakan sebuah organisasi sosial wadah pembinaan dan pengembangan generasi muda yang tumbuh dan berkembang atas dasar tanggung jawab dan kesadaran sosial dari, oleh dan untuk masyarakat terutama generasi muda di wilayah desa/kelurahan atau komunitas sederajat dan terutama bergerak dibidang usaha kesejahteraan sosial. Berikut ini salah satu contoh kegiatan yang dilakukan oleh karang taruna di 
RW 10 Permata Mansion pada saat merayakan kegiatan Hari Ulang Tahun RI yang ke 74 .

Sebagai perwujudan dan komitmen karang taruna dalam memberikan

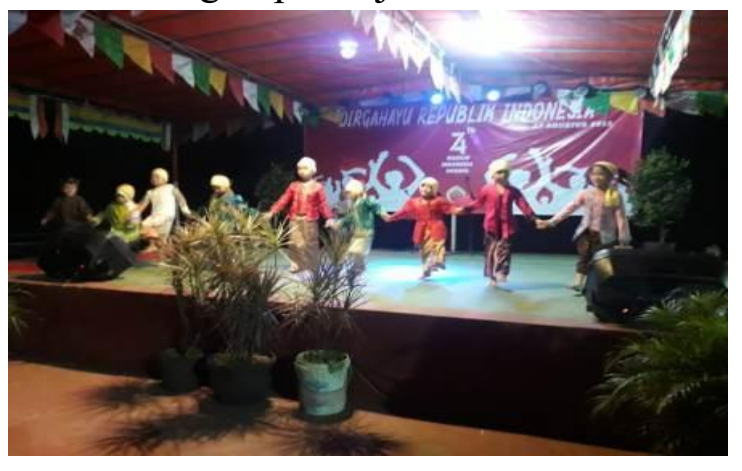
sumbangsih terhadap masyarakat yang berada di wilayah RW 10 Permata Mansion Serua, maka mereka sering mengadakan kegiatan-kegiatan dalam rangka memperingati hari besar nasional maupun hari besar islam untuk memeriahkan perayaan hari besar tersebut. Sebagai upaya untuk medapatkan dana maka mereka

Foto: Kegiatan HUT RI membuat proposal kegiatan. Secara etimologis kata proposal berasal dari bahasa Inggris, yaitu propose yang memiliki makna pengajuan/mengajukan atau permohonan. Proposal merupakan suatu rencana yang disajikan dalam bentuk rancangan kegiatan dengan tujuan untuk menawarkan konsep, ide, maupun gagasan kepada pihak lain sehingga bisa mendapatkan dukungan berupa ijin, dana, dan persetujuan yang dituangkan dalam bentuk tulisan. Tulisan dalam suatu proposal harus disusun secara detail, sistematis dan menyeluruh karena akan dijadikan pedoman kerja dalam pelaksanaan kegiatan yang direncanakan, Hasyim dan Nugrahanto (2014:207). Tulisan dalam suatu proposal harus disusun secara detail, sistematis dan menyeluruh karena akan dijadikan pedoman kerja dalam pelaksanaan kegiatan yang direncanakan. Beberapa komponen yang harus diperhatikan di dalam proposal adalah isi, bahasa dan sistematika penulisan unsur-unsur yang ada di dalamnya seperti latar belakang, tujuan, manfaat, dll.

Untuk menyukseskan acara, disamping menyertakan proposal tersebut, pihak yang melakukan pengajuan juga harus mempersiapan surat-surat dalam bentuk resmi yang akan dikirimkan kepada pihak-pihak yang terkait. Surat menyurat merupakan suatu sarana untuk meyampaikan informasi atau pernyataan secara tertulis kepada pihak lain baik atas nama pribadi ataupun karena kedinasan. Surat juga merupakan wakil resmi dari yang mengirim untuk membicarakan masalah yang dihadapi. Menurut Karyaningsih (2018:9) surat adalah alat untuk menyampaikan suatu maksud secara tertulis. Penyampaian maksud surat dari suatu pihak kepada pihak lain dapat

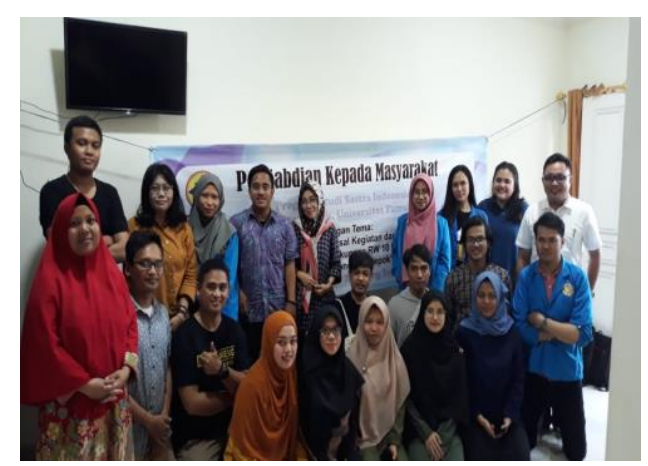
atas nama atau perseorangan atas nama jabatan dalam suatu organisasi. Kegiatan saling berkirim surat oleh perorangan atau organisasi disebut surat-menyurat atau korespondensi. Para pelaku dalam korespondensi disebut koresponden. Menurut 
Yusuf dalam Arlita dan Nelis (2013:269), "korespondensi atau surat menyurat dalam suatu kantor, instansi, atau organisasi dibagi menjadi dua, yakni: korespondensi eksteren, yaitu hubungan surat-menyurat yang dilakukan oleh kantor atau bagian-bagiannya dengan pihak luar. Korespondensi Interen, yaitu hubungan surat-menyurat yang dilakukan oleh orang-orang dalam suatu kantor". Surat menyurat yang biasa disebut arsip korespondensi, merupakan alat penyampaian informasi atau keterangan-keterangan (keputusan, pernyataan, pemberitahuan, dan permintaan) secara tertulis dari satu pihak kepada pihak lain Wursanto dalam susanti dkk (2018:20).

Bertolak dari latar belakang tersebut, terlihat bahwa karang taruna masih memiliki kendala dalam membuat proposal kegiatan sesuai dengan standar penulisan proposal kegiatan yang ideal sehingga dana yang diperoleh dari sponsor maupun dari donator masih belum maksimal. Tidak hanya itu, mereka juga memiliki kendala dalam menulis surat-menyurat dengan menggunakan bahasa resmi sesuai dengan standar penulisan bahasa Indonesia yang baik dan benar. Maka dari itu perlu adanya penanganan serius dari akademisi untuk memberikan penyuluhan tentang tata cara penulisan proposal kegiatan dan surat menyurat dengan menggunakan bahasa resmi yang baik dan benar sesuai dengan kaidah bahasa Indonesia.

\section{METODE PELAKSANAAN KEGIATAN}

Rencana kegiatan yang akan dilakukan untuk menyukseskan kegiatan pengabdian ini, yaitu:

a. Tahap persiapan. Pada tahap ini, Persiapan ini difokuskan dengan menyiapkan semua peralatan yang dibutuhkan untuk melaksanan kegiatan ini. Pada tahapan ini pelaksana memulai dengan melakukan studi literatur dan melakukan koordinasi dengan instansi terkait serta tokoh masyarakat untuk melakukan kegiatan pelatihan penulisan proposal kegiatan dan surat menyurat resmi serta sosialisasi dalam penerapan penulisan proposal dan surat menyurat resmi sesuai dengan kaidah bahasa Indonesia yang baik dan benar.

b. Penentuan Lokasi. Pada tahap ini dilakukan kunjungan ke lokasi untuk menentukan tempat (lokasi) dimulainya pelatihan penulisan proposal kegiatan dan surat menyurat resmi. Pelaksana PKM memilih tempat PKM yaitu dengan mengambil lokasi di RW 10 Permata Mansion Serua. Dalam memilih lokasi, kami mempertimbangkan dengan jarak yang kami tempuh dari Universitas ke lokasi pengabdian sehingga kegiatan ini dapatr berlangsung dengan efektif.

c. Perancangan kebutuhan. Tahapan ini merupakan tahapan yang paling penting mengingat bahwa kebutuhan selama kegiatan PKM harus direncanakan dengan baik sehingga semua kebutuhan dapat terpenuhi dengan maksimal dan acara berjalan dengan lancar. Adapun tahapan yang dilakukan dalam perancangan kebutuhan secara berurutan adalah sebagai berikut:

1. Perancangan materi sosialisasi pentingnya penulisan proposal kegiatan dan surat menyurat resmi. 
2. Perancangan materi tentang prosedur penulisan proposal kegiatan dan surat menyurat resmi.

d. Perancangan alat. Pada tahapan ini pelaksana berupaya untuk menyiapkan peralatan yang dibutuhkan selama kegiatan berlangsung. Perancangan alat secara berurutan adalah sebagai berikut:

1. Menyiapkan sound system, pada tahapan ini pelaksana menyiapkan sound system agar pada saat kegiatan berlangsung suara pembicara dapat terdengar secara jelas.

2. Menyiapkan proyektor, pada tahapan ini pelaksana menyiapkan proyektor agar pada saat kegiatan berlangsung materi yang ingin disampaikan oleh pembicara dapat dibaca dengan jelas sehingga mempermudah pemahaman.

3. Menyiapkan kertas. Pada tahapan ini pelaksana menyiapkan kertas agar pada saat kegiatan berlangsung mitra dapat secara langsung mempraktekan hasil dari pelatihan tulis-menulis.

4. Menyiapkan printer. Pada tahapan ini pelaksana kegiatan menyiapkan printer sehingga mitra dapat dengan mudah mencetak apa yang telah ditulis pada saat kegiatan berlangsung.

\section{HASIL DAN PEMBAHASAN}

Permasalahan mitra merupakan sesuatu yang perlu dipahami oleh kedua belah pihak sehingga persoalan yang dihadapi mitra dapat dicarikan solusinya. Persoalan yang dihadapi oleh Karang Taruna di RW 10 Permata Mansion dalam penulisan proposal kegiatan dan surat menyurat adalah sebagai berikut ini:

1. Permasalahan utama yang dihadapi oleh mitra adalah sumber daya manusia yang kurang pengetahuan dan pemahaman mengenai fungsi serta manfaat proposal kegiatan dan surat menyurat dalam bentuk resmi.

2. Permasalah kedua adalah sumber daya manusia yang kurang memahami infomasi mengenai prosedur pembuatan proposal dan surat menyurat dalam bentuk resmi untuk penyelenggaraan suatu kegiatan.

3. Permasalah ketiga adalah sumber daya manusia yang kurang berpengalaman dalam menulis proposal kegiatan dan surat menyurat resmi.

4. Permasalahan keempat adalah langkah penyusunan proposal dan suratmenyurat yang cukup rumit sering kali membuat pihak mitra mengalami kesulitan.

Berdasarkan permasalahan utama mitra yang telah dijelaskan pada poin sebelumnya, maka solusi permasalahan yang di tawarkan kepada mitra adalah:

a. Sebagai upaya menyelesaikan permasalahan utama yang dihadapi oleh mitra yaitu sumber daya manusia yang kurang pengetahuan dan pemahaman mengenai fungsi serta manfaat proposal kegiatan dan surat menyurat dalam bentuk resmi, maka solusi yang kami tawarkan adalah dengan memberikan pelatihan tentang tata cara penulisan proposal kegiatan dan surat menyurat sesuai dengan kaidah tata cara penulisan yang ilmiah.

b. Sebagai upaya menyelesaikan permasalahan kedua, yaitu sumber daya manusia yang kurang memahami infomasi mengenai prosedur pembuatan proposal dan 
surat menyurat dalam bentuk resmi untuk penyelenggaraan suatu kegiatan, maka solusi yang kami tawarkan adalah dengan memberikan informasi mengenai prosedur penulisan proposal kegiatan dan surat menyurat sesuai dengan kaidah tata cara penulisan yang ilmiah.

c. Sebagai upaya menyelesaikan permasalahan ketiga yaitu sumber daya manusia yang kurang berpengalaman dalam menulis proposal kegiatan dan surat menyurat resmi, maka solusi yang kami tawarkan adalah dengan memberikan pelatihan dan sharing pengalaman tentang penulisan proposal kegiatan dan surat menyurat sesuai dengan kaidah tata cara penulisan yang ilmiah.

d. Sebagai upaya menyelesaikan permasalahan keempat, langkah penyusunan proposal dan surat-menyurat yang cukup rumit sering kali membuat pihak mitra mengalami kesulitan, maka solusi yang kami tawarkan adalah dengan memberikan pemahaman bahwa penulisan proposal kegiatan dan surat menyurat sesuai dengan kaidah tata cara penulisan yang ilmiah adalah tidak rumit.

\section{KESIMPULAN DAN SARAN}

Hasil kegiatan ini dapat memberikan manfaat bagi karang taruna di RW 10 Permata Mansion maupun civitas akademika. Manfaat bagi para peserta pelatihan adalah untuk menambah wawasan dan melatih dalam penyusunan proposal kegiatan dan surat menyurat dalam bentuk resmi guna penyelenggaraan suatu kegiatan di daerah sekitar anggota pelatihan. Manfaat bagi civitas akademika dari adanya kegiatan ini yaitu sebagai tempat untuk mengamalkan ilmu sebagai wujud peran serta secara nyata pengabdian diri kepada masyarakat.

Disarankan kepada tenaga pengajar dan akademisi untuk lebih memperluas jangkauan dalam menyebarluaskan informasi kepada karang taruna di wilayak Tangerang Selatan maupun Depok sehingga masyarakat luas dapat merasakan manfaat dari kegiatan PKM yang diadakan oleh akademisi di lingkungan Program Studi sastra Indonesia.

\section{DAFTAR PUSTAKA}

Arlita, Roza dan Nelisa, Malta. (2013). "Problematika Korespondensi Resmi Bagi Pegawai Kantor Perpustakaan Arsip dan Dokumentasi Kabupaten Tanah Datar.” Jurnal Ilmu Informasi Perpustakaan dan Kearsipan Vol. 2, No. 1, September 2013, Seri D.

Hasyim, Muhammad dan Nugrahanto, Ganang. (2014). "Pelatihan Pembuatan Proposal Kegiatan Pada Remajadusun Ngepuh Lor, Desa

Banyusidi, Pakis, Magelang, Jawa Tengah”. Jurnal Inovasi dan Kewirausahaan, Volume 3 No. 3, September 2014 Halaman 206-210.

Karyaningsih, Ponco Dewi. (2018). Korespondensi Surat Bisnis dan Dinas. Yogyakarta: Samudra Biru.

Susanti, dkk. (2018). "Pengembangan Model Aplikasi E-Surat Sebagai Upaya Peningkatan Kompetensi Bidang Manajemen Rekod". Jurnal Gama Societa, Vol. 1 No. 1, Januari 2018, 20 - 30. 
